\title{
What Golfer Want When Playing Golf? (A Lesson Learned from Dago Heritage Golf Course Bandung)
}

\author{
T. A. Anwar, G. Sugandi, M. H. Mohd Saudi, and H. O. Sinaga
}

\begin{abstract}
The potential of golf tourism in Bandung is able to attract both local and international tourists. This is not apart from the image of Bandung as one of the best tourist destination in Indonesia. The development of golf in Bandung is also inseparable from the development of golf in Indonesia.

One of the habits of golfers is playing on a golf course that they have never played. Nevertheless, there is still one golf course that is their favorite in every city. Like for example in Bandung. In Bandung, there are 3 golf courses namely Dago Heritage Golf Course, Mountain View, and Bandung Indah Golf and Country Club. From the existing golf course, Dago Heritage Golf Course is Golfer's main choice to play in Bandung, although the quality of the field is not better than its competitors. Dago Heritage Golf Course also offers higher prices than Bandung Indah Golf \& Country Club. However, Golfer still choose Dago Heritage Golf Course. This research is interesting and important to do because golf can increase tourism potential in Bandung. This is in line with the number of local and foreign tourists who come in Bandung. So hopefully can be important things sought by Golfer when playing Golf.

The research method used is descriptive-verification method. In this study, the golf course in Bandung and still choose Dago Heritage Golf Course as the main choice. The number of respondents was 115 respondents. Sampling using simple random sampling technique. Data collection in this study was conducted by interview, questionnaire, and direct observation to obtain primary data. Path analysis is also used in this study.

The facilities offered and the quality of the golf course turned out to be the main thing sought by Golfer. They prefer a golf course that they feel comfortable through the bonds of kinship and intimacy created. Dago Heritage Golf Course. However, improvements in the quality of the field and existing facilities have been enhanced to improve their comfort. The other thing they are looking for from golf course is the availability of driving range, hole in one, the availability of female caddy, and so on.
\end{abstract}

Index Terms - Customer value, experiential marketing, golf, repurchase decision.

\section{INTRODUCTION}

The potential of golf tourism in Bandung is able to attract tourists not only domestic tourists but also abroad, especially from Malaysia and Singapore. This is supported by the increased frequency of direct flights from both countries to Bandung.

Manuscript received March 31, 2018; revised June 12, 2018.

T. A. Anwar, G. Sugandi, and M. H. Mohd Saudi, H. O. Sinaga are with Widyatama University, Bandung, West Java, Indonesia (e-mail: tezza.anwar@widyatama.ac.id,_ gagan.sugandi@widyatama.ac.id, haizam@iumw.edu.my, obsatar.sinaga@unpad.ac.id).
The development of golf in Bandung also developed in line with the development of golf in Indonesia. Therefore, the golf course in Bandung was also growing. The golf course in Bandung is as follows: Mountain View Golf Club; Bandung Indah Golf \& Country Club (BIG); and Dago Heritage Golf Course [1]. In addition to these three golf courses, there are also several golf courses around Bandung. For examples Bandung Giri Gahana Golf Course in Jatinangor and Poltak Golf Course in Lembang and the latest is the golf course at Kota Baru Parahyangan, Padalarang.

One of the habits of golfer is to try every field in a certain city because every golf course has different designs. This causes each golf course has its own challenges that make the golfer curious. However, in the end each golfer will choose a golf course that is the main choice in a particular city.

In addition, each of the golf courses has facilities that support golf activities. Although there are facilities that are not as complete as other golf courses. Completeness of facilities and quality of the field to be a special attraction for the golfer. Mountain View Golf Course and Bandung Indah Golf \& Country Club have better facilities when compared with Dago Heritage Golf Course. However, Dago Heritage Golf Course actually has a better market share compared to Bandung Indah Golf \& Country Club. Though facilities owned by Bandung Indah Golf \& Country Club more complete when compared with Dago Heritage Golf Course. Related to the market share of golf course in Bandung, Nadya [2] stated that the sale at Bandung Indah Golf \& Country Club. Whereas Green Fee at Dago Heritage Golf Course is higher than in Bandung Indah Golf \& Country Club. In terms of facilities, Bandung Indah Golf \& Country Club has a lot more facilities than Dago Heritage Golf Course which is a sauna, jacuzzi, driving range, putting green, golf academy, and even multipurpose hall which is not owned by Dago Heritage Golf Course. But Dago Heritage Golf Course can still achieve greater market share than Bandung Indah Golf \& Country Club which has more complete facilities and cheaper price.

There is one interesting thing that can be seen from the graph above that is the sale at Dago Heritage Golf Course is higher than the sales of Bandung Indah Golf \& Country Club. Whereas Green Fee at Dago Heritage Golf Course is higher than in Bandung Indah Golf \& Country Club. In terms of facilities, Bandung Indah Golf \& Country Club has much more complete facilities than Dago Heritage Golf Course which is sauna, jacuzzi, driving range, putting green, golf academy, and even multipurpose hall which is not owned by Dago Heritage Golf Course. But Dago Heritage Golf Course can still achieve greater market share than 
Bandung Indah Golf \& Country Club which has more complete facilities and cheaper price.

The facilities provided by each golf course vary according to the ability and location availability of each golf course. The availability of facilities can also be different due to the demand and need of the golfer. Given the differences in the facilities provided, the three golf courses also have different pricing strategies.

This research is intended to find out what golfers are looking for when playing golf. In addition, what efforts can be made to improve the intention of the golfer in order to optimize the city's tourism potential. This study will explore how the impact of experiential marketing on customer value and how the impact of experiential marketing and customer value on the decision to play golf again at Dago Heritage Golf Course.

\section{LITERATURE REVIEW}

\section{A. Experiential Marketing}

According to Schmitt [3], the initiator of experiential marketing, the framework of experiential marketing has two aspects: 1) five types of experiences, called strategic experiential modules (SEMs), which form the strategic underpinning of experiential marketing, and 2) experience providers (Expros), the tactical tools. Holbrook [4] criticizing Schmitt for positioning this rather modest conceptual framework as "a key strategic planning tool" of experiential marketing. We stress that marketing planning tool is tactical, not strategic. Experience marketing concept is based on experiences, not only on specific activities that are experiential in nature.

Similansky [5] defines experiential marketing as a "process of identifying and satisfying customer needs and aspirations profitably, engaging them through two-way communications that bring brand personalities to life and add value to the target audience". Experiential marketing helps to crate experience and emotions to the customers. Hauser [6] describes experiential marketing as a holistic approach to the customer/brand relationship.

Experiential marketing is being used by more and more businesses to forge experiential connections with customers nowadays [3]. Schmitt [7] proposed the concept of strategic experiential modules (SEMs) that managers can use to create different types of customer experiences for their customers. The experiential modules to be managed in experiential marketing include sensory experience (SENSE), affective experience (FEEL), creative cognitive experiences (THINK), physical experiences, behaviors and lifestyles (ACT) and social-identity experiences that result from relating to a reference group of culture (RELATE).

\section{B. Customer Value}

Customer value is one of the important things in giving the consumer perception of a product. According to Kotler and Armstrong [8], customer value is the ratio between all profits and all costs incurred to receive a given offer. According to Kotler and Keller [9] the value of the customer is the difference between total customer value and total customer cost. The total customer value is a set of benefits expected by the customer of the product or service.
The total customer cost is a set of costs expected by consumers issued by consumers to evaluate getting, using and disposing of a product or service. Meanwhile, according to Best in Sumarwan [10], customer value is a benefit obtained by customers minus the cost of purchase. Based on this concept, customer value comes from economic benefits, customer benefits, and emotional benefits

According to Best in Sumarwan [10], that customer value can be created through several approaches, namely: Cost of life cycle and value creation; Price performance and value creation; Perceived benefits and value creation; Customer benefits; and Emotional benefits and value creation.

According to Kotler and Keller[9], customer value is shaped by two key elements: Total customer value (product value; value of service; personnel or employees; and imagery); and Total customer cost (monetary costs; time cost; energy costs; and psychic costs)

Meanwhile, according to Sweeney and Soutar in Tjiptono [11], the value dimension consists of four dimensions, namely: Emotional Value; Social Value; Monetary Value; and Performance Values.

Then according to Buttle [12], customer value can be measured in terms of cost as follows: Money (price offered); Search fee; and Physical costs.

\section{Repurchase Decision}

Consumer purchasing decisions are very diverse, there is a simple and complex. According to Kotler and Keller [9] purchasing decisions are all experience in learning, selection, use, and even product disposal. According to Kotler and Armstrong [8] the purchase decision is the consumer's decision about the brand to be purchased. Meanwhile, according to Pride and Ferrel [13]) customer purchase decision is a series of choices made by consumers before making a purchase, so after that they are willing to buy.

Kotler and Armstrong [8] put forward several factors that influence consumer purchasing decisions: Culture; Social Factors; Personal Factors; and Psychological Factors.

Furthermore, Kotler and Keller [9] argue that the process of purchasing decision making can be divided into five stages as : problem recognition - information search evaluation of alternatives - purchase decision - post purchase decision.

According to Sutisna in Goseldia [14], the dimensions to measure purchasing decisions taken by consumers include: Benefit Association; Priority in buying; and Frequency of purchase.

Meanwhile, according to Hsu, Chang and Sweeney in Goseldia [14], indicators of purchasing decisions are as follows: The desire to use the product; The desire to buy the product; Priority of purchase on the product; Availability of time to get the product; Confidence to buy the product; Products as expected; and Consideration of the benefits of the product.

\section{HYPOTHESIS}

Hypothesis in this research is as follows:

a. Experiential marketing affected repurchase intention. 
b. Customer value affected repurchase intention.

c. Experiential marketing affected customer value.

\section{MethodOLOGY}

This study is conducted in Dago Heritage Golf Course and the respondents are golfer who had played in three golf courses in Bandung but still chose Dago Heritage Golf Course as the main choice. The number of this kind of golfer can not be known because the Golf Course does not have the data. Therefore, the population is unknown. Based on iteration method, this survey requires to gather minimum data of 115 data. This survey succeeds in gathering 120 data to be analyzed. The pilot study was did to first 30 respondents and the result showed that the questionnaire was reliable based on the Cronbach's Alpha value that is more than 0.5 [15]. It means that the questionnaire is understandable and targeted the right audience. For the data collection, random sampling was done. It means that all golfer who meets the criteria have the same chance to participate in the study.

\section{DISCUSSION}

\section{A. Demographic Profile of the Golfer}

From 120 data that is analyzed, all men. They have more than 3 times playing at Dago Heritage Golf Club. And they have also tried both other fields (Mountain View Golf Course and Bandung Indah Golf \& Country Club) but again chose to play at Dago Heritage Golf Club. All of them are also tourists who come from outside Bandung (both local and foreign tourists). They come to Bandung mostly for vacation.

\section{B. Descriptive Analysis Results}

The response of the golfer to experiential marketing, customer value and repurchase decision, can be seen in TABLE I as follow :

TABLE I : DESCRIPTIVE ANALYSIS RESULTS

\begin{tabular}{lcc}
\hline \multicolumn{1}{c}{ VARIABLES } & $\%$ & CATEGORY \\
\hline $\begin{array}{l}\text { Average Experiential } \\
\text { Marketing }\end{array}$ & 81 & Very High \\
\hline Average of Benefit & 87 & High \\
Average of Cost & 64 & Quite Low \\
\hline Average Repurchase Decision & 82 & Purchase Again \\
\hline
\end{tabular}

Golfer feel a memorable and enjoyable experience while playing at Dago Heritage Golf Course. They are very impressed with the hospitality and comfort and family atmosphere that is on the golf course. Every employee is very communicative and willing to help them when getting into trouble while playing golf.

Associated with the benefits that golfer gets when playing at Dago Heritage Golf Course, then they feel the benefits are very large. The quality of service provided by employees is very valuable to the golfer. Friendliness, speed of service, and empathy from employees make the golfer feel comfortable. Although in terms of field quality and facilities available is not too good when compared with other golf course.

In terms of cost dimension, psychological costs are very prominent among other costs. The low psychological costs are due to the security and convenience of services provided by employees. Golfer who first played in Dago Heritage can feel it. And of course it's different and they do not find on other golf courses. In terms of energei and the time required to play at Dago Heritage Golf Course is also quite low. Because of the location of the golf course is quite strategic and easy to travel from various areas. So, overall, the benefits gained by golfer are greater when compared to the costs that must be incurred.

Overall, the golfer will come back to Dago Heritage Golf Course. They are content to play golf at Dago Heritage Golf Course. Satisfaction is caused by a sense of comfort and security. This comfort arises because of the friendliness of each crew on the golf course and the atmosphere of kinship. This is what distinguishes Dago Heritage Golf Course with other golf courses. So the golfer did not really question the lack of facilities owned by Dago Heritage Golf Course.

\section{Results of Hypothesis Testing}

After calculation for path analysis using Lisrell 9.30 (student version), then the result of path diagram as the Fig. 1 below :

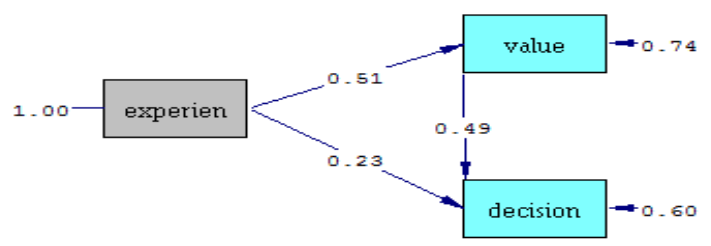

Fig. 1. Path Diagram

In addition to the path diagram, also generated structural equations (influence of experiential marketing to customer value) as follows:

$$
\begin{array}{cc}
\text { value }=0.51 * \text { experien, Errorvar. }=0.74, \mathrm{R}^{2}=0.26 \\
(0.079) & (0.096) \\
6.42 & 7.68
\end{array}
$$

From the above structural equations, the hypothesis test is as TABLE II below:

TABLE II: HYPOTHESIS TEST OF STRUCTURAL EQUATIONS I

\begin{tabular}{llllll}
\hline \multicolumn{1}{c}{ Hypothesis } & $\mathbf{t}_{\text {count }}$ & $\mathbf{t}_{\text {table }}$ & $\begin{array}{c}\text { Res } \\
\text { ult }\end{array}$ & \multicolumn{1}{c}{$\begin{array}{c}\text { Statistical } \\
\text { Conclusion }\end{array}$} \\
\hline $\begin{array}{l}\text { Experiential marketing } \\
\text { does not affect } \\
\text { customer value }\end{array}$ & 6.42 & $\begin{array}{l}1.9 \\
8\end{array}$ & $\begin{array}{l}\text { Sig } \\
\text { nifi } \\
\text { cant }\end{array}$ & $\begin{array}{l}\mathrm{H}_{0} \\
\text { Experience rejected. affect } \\
\text { customer value }\end{array}$ \\
\hline
\end{tabular}

The table above shows that experiential marketing has a significant influence on customer value. The influence of experiential marketing on customer value can be seen in the following TABLE III:

TABLE III: THE INFLUENCE OF EXPERIENTIAL MARKETING ON CUSTOMER

\begin{tabular}{lcccc}
\multicolumn{3}{c}{ VALUE } & & \\
\hline & Coefficient & Impact & $\begin{array}{c}\text { Residual } \\
\text { Factor }\end{array}$ \\
\hline $\begin{array}{l}\text { Experiential } \\
\text { influencing } \\
\text { value }\end{array}$ & $\begin{array}{c}\text { marketing } \\
\text { customer }\end{array}$ & 0,51 & $26,01 \%$ & $73,99 \%$ \\
\hline
\end{tabular}


The table above shows that experiential marketing is quite closely related to customer value. This shows that although experiential marketing has a significant effect on customer value but the effect is quite small on customer value. Their golfing experience at Dago Heritage Golf Course does not significantly affect their customer value on the golf course as they have played several times and not many changes have been felt in terms of existing facilities. Improvement just emerged from the friendliness and kinship that is on the golf course.

Meanwhile, structural equations for experiential marketing and customer value influence on repurchase decision are as follows: 0.40

decision $=0.49 *$ value $+0.23 *$ experien, Errorvar. $=0.60, R^{2}=$
$(0.083) \quad(0.083)$
$5.92 \quad 2.76$
(0.078)
7.68

From the above structural equations, the hypothesis test is show as TABLE IV below:

TABLE IV: HyPOTHESIS TEST OF STRUCTURAL EQUATION II

\begin{tabular}{|c|c|c|c|c|}
\hline Hypothesis & $t_{\text {count }}$ & $\mathbf{t}_{\text {table }}$ & Result & $\begin{array}{c}\text { Statistical } \\
\text { Conclusion }\end{array}$ \\
\hline $\begin{array}{lr}\text { Experience } & \text { does } \\
\text { not } & \text { affect } \\
\text { repurchase } & \\
\text { decision } & \end{array}$ & 5.92 & 1.98 & $\begin{array}{l}\text { Signifi } \\
\text { cant }\end{array}$ & $\begin{array}{l}\mathrm{H}_{0} \quad \text { rejected. } \\
\text { Experience affect } \\
\text { repurchase decision }\end{array}$ \\
\hline $\begin{array}{ll}\text { Customer value } \\
\text { does not affect } \\
\text { repurchase } \\
\text { decision }\end{array}$ & 2.76 & 1.98 & $\begin{array}{l}\text { Signifi } \\
\text { cant }\end{array}$ & $\begin{array}{lr}\mathrm{H}_{0} & \text { rejected. } \\
\text { Customer } & \text { value } \\
\text { affect repurchase } \\
\text { decision }\end{array}$ \\
\hline
\end{tabular}

The table above shows that experiential marketing has a significant influence on repurchase decision. Similarly, the customer value has a significant effect on repurchase decision. The magnitude of the influence of each variable can be seen in TABLE $\mathrm{V}$ as follow:

TABLE V: INFLUENCE ON REPURCHASE DECISION

\begin{tabular}{lcccc}
\hline \multicolumn{4}{c}{ TABLE V: INFLUENCE ON REPURCHASE DECISION } \\
\hline $\begin{array}{l}\text { Coefficient } \\
\text { influencing } \\
\text { decision }\end{array}$ & $\begin{array}{c}\text { marketing } \\
\text { repurchase }\end{array}$ & 0,23 & $\begin{array}{c}\text { Residual } \\
\text { Factor }\end{array}$ \\
\hline $\begin{array}{l}\text { Customer } \\
\text { influencing } \\
\text { decision }\end{array}$ & $\begin{array}{c}\text { value } \\
\text { repurchase }\end{array}$ & 0,49 & $24,01 \%$ & $94,71 \%$ \\
\hline
\end{tabular}

Customer value affects greater repurchase decision when compared to experiential marketing. This shows that to improve repurchase decision, it is focused firstly to increase customer value. Golfer sees that the benefits of service and people are more prominent than other benefits. This makes the psychological cost of the golfer low due to the comfort and safety that is gained when playing at Dago Heritage Golf Course. Nevertheless, improving the quality of existing field and facilities is always done to improve customer value.

In terms of experiential marketing, the effect on repurchase decision is low. Golfer already feel the experience of playing a comfortable and safe golf. This comfort and safety they do not get from other golf courses. The experience of playing at Dago Heritage Golf Course is a memorable experience for the golfer. So they decided to play golf again there.

\section{CONCLUSION}

The decision to play golf at Dago Heritage Golf Course is influenced by the experiential marketing and customer value of the golfer. Although, greater customer value affects the decision. This shows that if you want to make the golfer to return to play, then the added value of the golf course is always enhanced. The main focus not only from the facilities, but also from the services provided by the golf course staff both in the form of good service and friendliness and comfort created.

Golfer is a relatively unique individual but has some similarities. They have the same habit of playing on the new golf course but will eventually return to play on a golf course that they feel comfortable with. Convenience sought is a familial relationship created through personal communication and empathy from the golf course staff from Bag Drop staff to caddies that deal directly with the golfer. Every golfer wants to be noticed by the golf course staff. In fact, staff who remember and call their names become fun and add value to the golf course. In addition, the security factor is also very desirable. As an example is when they missed the items and the items are still there or stored by the golf course staff then this becomes an added value for the comfort of the golfer. This comfort they rarely encounter on a golf course. Therefore, the main focus of golf course management should be shifting towards this.

Meanwhile, the completeness of the golf course facilities and field quality became the second thing that concerns them. However, improvements in the quality of the field and the existing facilities are always done to improve their comfort. The facilities they want to have on the golf course are availability of cafe or restaurant, driving range, gift hole in one, the availability of female caddy (for male golfer), and so on.

\section{ACKNOWLEDGMENT}

Our thanks to Nadya Rosiana for the inspiration and allowing us to develop the study.

\section{REFERENCES}

[1] Deagrathia, Delila. 5 Lapangan Golf di Sekitar Bandung. [Online]. Available: http://www.infobdg.com/v2/5-lapangan-golf-di-sekitarbandung-2/

[2] R. Nadya, "Kualitas jasa dan harga dal am menentukan minat untuk bermain kembali di dago golf course bandung," Thesis, Business and Management Faculty, Widyatama University, 2016.

[3] B. Chmitt, "Experiential marketing: How to get customers to sense, feel, think, act and relate to your company and brands," The Free Press, New York, USA, 1999a.

[4] M. B. Holbrook, "The millennial consumer in the texts of our times: Experience and entertainment," Journal of Macromarketing, vol. 20, no. 2, pp. 178-192. 2000.

[5] S. Shaz, Experiential Marketing: A Practical Guide to Interactive Brand Experiences, London: Kogan Page, 2009.

[6] E. Hauser, Brandweek: Experiential Marketing, in Experiential Marketing Forum, 26 July 2007.

[7] B. Schmitt. Experiential Marketing. Journal of Marketing Management. [Online]. Available: http://dx.doi.org/10.1362/026725799784870496

[8] K. Philip and G. Amstrong, Principles of Marketing, 15 $5^{\text {th }}$ Edition New Jersey: Pearson education limited, 2014.

[9] K. P. D. K. L. Keller, Marketing Management, 15th Edition New Jersey: Pearson Education Limited, 2016. 
[10] S. Ujang, Perilaku Konsumen, Jakarta: Ghalia Indonesia, 2010.

[11] T. Fandy, Manajemen Jasa, Edisi Keempat, Yogyakarta: Penerbit Andi, 2005.

[12] B. Francis, Customer Relationship Management, Bayumedia, Jakarta, 2007.

[13] P. D. Ferrel, Marketing Principles, Edisi Terjemahan, Jakarta: Erlangga, 2012.

[14] G. O. Kurnia. Analisis Varian Pengaruh Interaksi Harga dan Citra merek terhadap Keputusan Pembelian, 2011.

[15] J. F. Hair et al., Multivariate Data Analysis, 7th edition, New Jersey: Pearson Education Inc., 2010.

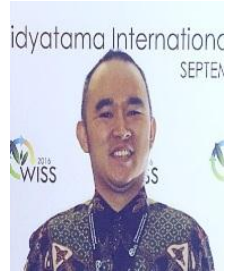

Tezza Adriansyah Anwar was born in Bandung, May, $24^{\text {th }} 1980$. Anwar finished the doctoral degree at Management Science Department, Faculty of Economic and Business, Padjadjaran State University, Bandung West Java, Indonesia in 2016 majoring marketing. The master degree was earned in 2007 at Magister Management Department, Faculty of
Economic and Business, Padjadjaran State University, Bandung, West Java, Indonesia, also majoring marketing. And his graduate degree was earned in 2003 at International Relations Department, Padjadjaran State University, Bandung, West Java Indonesia.

Currently he is a lecturer of Widyatama University, Bandung, West Java, Indonesia. He is also acted as DIRECTOR of Post-Graduate School of Widyatama University. And former DEAN of Business and Management Faculty at the same university. His previous publications were at International Journal of Advanced and Applied Sciences (2017), $9^{\text {th }}$ International Conference on Information Management and Engineering (2017), and International Journal of Management Sciences and Business research - Volume 5 (2016). The field of research that is engaged is marketing and entrepreneurship.

Dr. Tezza Adriansyah Anwar also a member of Asia-Pacific Consortium of Researchers and Educators (APCoRE) and Professional Member of Association for Computing Machinery (ACM). 